$\mathbf{Q}$

\section{PENGELOLAAN ABU CANGKANG KELAPA SAWIT SEBAGAI BAHAN PEMBANGUN DETERJEN RAMAH LINGKUNGAN DI DESA KUAMANG KUNING KABUPATEN BUNGO}

\author{
Intan Lestari ${ }^{1)}$, Diah Riski Gusti ${ }^{2)}$, Nindita Clourisa Amaris Susanto ${ }^{3)}$, Edwin \\ Permana $^{4}$, Indra Lasmana Tarigan ${ }^{5}$ * \\ ${ }^{1)}$ Program Studi Kimia, Fakultas Sains dan Teknologi, Universitas Jambi \\ email: ilestari_15@unja.ac.id \\ ${ }^{2)}$ Program Studi Kimia, Fakultas Sains dan Teknologi, Universitas Jambi \\ email: diah@unja.ac.id \\ ${ }^{3)}$ Program Studi Kimia, Fakultas Sains dan Teknologi, Universitas Jambi \\ email: clourisa@unja.ac.id \\ ${ }^{4)}$ Program Studi Kimia, Fakultas Sains dan Teknologi, Universitas Jambi \\ email: edwinpermana@unja.ac.id \\ ${ }^{5)}$ Program Studi Kimia, Fakultas Sains dan Teknologi, Universitas Jambi \\ email: indratarigan@unja.ac.id
}

\begin{abstract}
ABSTRAK
Provinsi Jambi merupakan salah satu Provinsi penyumbang hasil perkebuan kelapa sawit dengan luas areal lahan mencapai 10 - 15 ton/ha/tahun ha dan mampu memproduksi $0.55 \%$ berupa limbang cangkang kelapa sawit dan tempurung kelapa sawit. Abu cangkang kelapa sawit mengandung banyak mineral seperti $\mathrm{SiO}_{2} 58,02 \% ; \mathrm{Al}_{2} \mathrm{O}_{3} 8,7 \% ; \mathrm{CaO} 12,65 \% ; \mathrm{Fe}_{2} \mathrm{O}_{3}$ $2,6 \% ; \mathrm{Na}_{2} \mathrm{O} 0,41 \% ; \mathrm{MgO} 4,32 \% ; \mathrm{K}_{2} \mathrm{O} 0.72 \% ; \mathrm{H}_{2} \mathrm{O} 1,97 \%$; serta hilang pijar 8.59\%, unsur $\mathrm{K}$ 7,5\%; $\mathrm{Ca} 1,5 \% ; \mathrm{Cl} 1,3 \% ; \mathrm{CO}_{3} 1,9 \% ; \mathrm{Mg} 2,8 \% ; \mathrm{Na} 1,1 \%, \mathrm{~N} 0.05 \% ; \mathrm{PO}_{4} 0,9 \%$ dan $\mathrm{SiO}_{2} 61 \%$. Tujuan pengabdian ini memberikan pelatihan dan keterampilan kepada masyarakat Desa Kuamang Kuning dalam memanfaatkan abu cangkang kelapa sawit menjadi material zeolite 4A sebagai bahan pembangun deterjen ramah lingkungan, yang mampu menurunkan tingkat kesadahan air akibat pencemaran limbah rumah tangga. Kegiatan dilakukan dengan memberikan penyuluhan tentang potensi limbah abu cangkang kelapa sawit, pengolahnnya sebagai bahan pembangun deterjen berbasis zeolite 4A, dan melakukan pelatihan. Pelatihan ini memberikan peningkatan kompetensi bagi masyarakat, sebanyak $90 \%$ masyarakat peserta pelatihan yang hadir merasakan manfaat program ini untuk menambah pengatahuan dan wawasan, $100 \%$ merasakan ada pengaruh peningkatan pengetahuan tentang deterjen sintesis dan bahayanya terhadap lingkungan, serta pengetahuan tentang potensi limbah abu cangkang kelapa sawit dan sekitar $80 \%$ masyarakat berminat untuk mengelola abu cangkan kelapa sawit sebagai salah satu alternatif peluang usaha, serta $75 \%$ berniat untuk meneruskan program ini.
\end{abstract}

Kata kunci: Sawit, Cangkang Kelapa Sawit, Zeolit 4A, Pembangun Deterjen

\section{ABSTRACT}

Jambi Province is one of the contributing provinces to oil palm plantation products with a land area of 10-15 tons/ha/years and is capable of producing 0.55\% in the form of palm oil shells and oil palm shells. Oil palm shell ash contains many minerals such as $\mathrm{SiO} 258.02 \%$; $\mathrm{Al}_{2} \mathrm{O}_{3}$ 8.7\%; $\mathrm{CaO} 12.65 \% ; \mathrm{Fe}_{2} \mathrm{O}_{3} 2.6 \% ; \mathrm{Na}_{2} \mathrm{O} \mathrm{0.41 \% ;} \mathrm{MgO} 4.32 \% ; \mathrm{K}_{2} \mathrm{O} \mathrm{0.72 \%} ; \mathrm{H}_{2} \mathrm{O} 1.97 \%$; and loss of glow 8.59\%, K elements 7.5\%; Ca 1.5\%; $\mathrm{Cl} \mathrm{1.3 \% ;} \mathrm{CO} 3$ 1.9\%; $\mathrm{Mg}$ 2.8\%; $\mathrm{Na}$ $1.1 \%, \mathrm{~N} 0.05 \% ; \mathrm{PO}_{4} 0.9 \%$ and $\mathrm{SiO} 261 \%$. This program aims to provide training and skills to the people of Kuamang Kuning Village in utilizing oil palm shell ash into zeolite 4A material as a building block for environmentally friendly detergents, which can reduce water hardness levels due to household waste pollution. The activity was carried out by providing counseling on the potential for oil palm shell ash waste, processing it as a building block for zeolite 4Abased detergents, and conducting training. This training provides increased competence for the community, as many as $90 \%$ of the training participants who attended felt the benefits of this program to increase knowledge and insight, 100\% felt that there was an effect of 
increasing knowledge about synthetic detergents and their dangers to the environment, as well as knowledge about the potential waste of oil palm shell ash and about $80 \%$ of the community are interested in managing the ash of the oil palm kernel as an alternative business opportunity, and $75 \%$ intend to continue this program.

Keywords: Palm Oil, Palm Shell, Zeolite 4A, Detergent Builder

\section{PENDAHULUAN}

Provinsi jambi merupakan salah satu provinsi di Pulau Sumatera yang memiliki peran yang cukup besar dalam menghasilkan beberapa komoditas unggulan hasil pertanian dan perkebunan seperti kelapa sawit, perkebunan karet, perkebunan lada yang secara langsung dapat meningkatkan pertumbuhan ekonomi daerah serta mampu memberikan sumbangan terhadap pendapatan Daerah Regional Bruto (PDRB). Dalam sebaran daerah di Provinsi Jambi, Kabupaten Bungo merupakan salah satu daerah yang menjadi pusat perkebunan sawit dan karet. Pengembangan areal perkebunan sawit dan karet di Kabupaten Bungo menghasilkan beberapa produk sampingan/ limbah perkebunan yang belum dapat dioptimalkan dengan baik, seperti akar batang, daun dan tandan kosong kelapa sawit [1].

Penelitian tentang kelapa sawit menyebutkan bahwa rata-rata produktivitas perkebunan kelapa sawit pada tahun 2018 mencapai 24 - 40 ton/ha/tahun, akan tetapi produktivitas kelapa sawit di Provinsi Jambi hanya berkisar $10-15$ ton/ha/tahun sehingga diartikan produktivitas sangat rendah. Kabupaten Bungo merupakan salah satu sentral perkebunan tanaman kelapa sawit yang ada di provinsi Jambi. Luas perkebunan kelapa sawit rakyat untuk komoditas kelapa sawit mencapai 97.630 ha dengan produksi mencapai 188.534 ton dengan rata-rata penerimaan petani per $\mathrm{Ha}$ adalah 1.963.264 Rupiah/bulan.

Melihat hasil produksi dan luas lahan perkebunan kelapa sawit sangat menguntungkan bagi ekonomi petani tetapi pencapaian pendapatan petani tergolong sangat rendah. Pendapatan petani sangat ditentukan pada tingkat harga dan jumlah produksi. Untuk menghasilkan produksi kelapa sawit yang maksimum maka, harus didukung dengan sarana dan prasarana serta adanya informasi mengenai kombinasi dalam penggunaan faktor produksi dalam mencapai pertumbuhan perkebunan kelapa sawit rakyat yang efisien [2]

Cangkang kelapa sawit merupakan salah satu jenis limbah padat yang paling banyak dihasilkan oleh pabrik kelapa sawit. Menurut Susanto (2017), dari satu ton tandan buah segar (TBS) yang diolah akan dihasilkan minyak sawit kasar (CPO) sebanyak 0.21 ton $(21 \%)$ serta minyak inti sawit (PKO) sebanyak 0.05 ton (5\%), dan sisanya berupa limbah dalam bentuk tandan buah kosong, serat, dan cangkang biji yang jumlahnya masing-masing berkisar 23\%, 13\%, dan 5,5 $\%$ dari tandan buah segar. Dengan kata lain ada $5.5 \%$ atau setara dengan 0,05 ton merupakan cangkang kelapa sawit yang memiliki kandungan utama Silikon Oksida $\left(\mathrm{SiO}_{2}\right)$, yang merupakan komponen yang 
bersifat reaktif dan memiliki aktivitas pozzalanik yang baik, yang dapat beraksi menjadi bahan keras dan kaku. Abu cangkang kelapa sawit mengandung banyak mineral seperti $\mathrm{SiO}_{2}$ 58,02\%; $\mathrm{Al}_{2} \mathrm{O}_{3}$ 8,7\%; $\mathrm{CaO} 12,65 \% ; \mathrm{Fe}_{2} \mathrm{O}_{3} 2,6 \% ; \mathrm{Na}_{2} \mathrm{O}$ 0,41\%; $\mathrm{MgO} 4,32 \% ; \mathrm{K}_{2} \mathrm{O} 0.72 \% ; \mathrm{H}_{2} \mathrm{O}$ 1,97\%; serta hilang pijar $8.59 \%$. Lebih dari itu abu cangkang kelapa sawit mengandung unsur K 7,5\%; $\mathrm{Ca} 1,5 \% ; \mathrm{Cl} 1,3 \% ; \mathrm{CO}_{3} 1,9 \% ; \mathrm{Mg}$ $2,8 \% ; \mathrm{Na} 1,1 \%, \mathrm{~N} 0.05 \% ; \mathrm{PO}_{4} 0,9 \%$ dan $\mathrm{SiO}_{2} 61 \%$ [2].

Silika merupakan bahan kimia yang pemanfaatannya sangat luar mulai dari pembuatan senyawa kimia, bidang seni, menakin, dan bidang elektrolit, termasuk zeolit. Dengan produksi kelapa sawit di Kabupaten Bungo 4 ton pada tahun 2018, berarti menghasilkan 0.22 ton cangkang kelapa sawit setiap tahunnya. Industri pengolahan sawit yang ada masih memiliki masalah dalam memanfaatkan limbah sawit, berupa tandan kosong dan cangkang kelapa sawit. Sehingga dengan potensi 0.22 ton cangkang kelapa sawit yang diubah menjadi abu cangkang sawit sebagai sumber silika untuk dimanfaatkan menjadi material maju sangat dibutuhkan [3].

Prospek memproduksi material aktif berupa zeolit dari silika sangat menguntungkan, karena merupakan material yang dapat dimanfaatkan diberbagai bidang, seperti di bidang pertanian, zeolit abu cangkang kelapa sawit bisa digunakan sebagai pupuk, penyerap logam berat dalam tanah, pembasmi herbisida dan fungisida [4].
Kemudian dalam bidang peternakan zeolite dapat digunakan sebagai penambahan ketahanan terhadap penyakit, kesehatan kandang, penyerapan kontaminan dan penggemukan [5]. Pada bidang industri kertas, zeolite dapat digunakan sebagai bahan pengisi, bahan penyerap tinta, dan sebagai bahan pembangun/pengisi deterjen serta mampu menurunkan tingkat kesadahan pada air. Selain pada proses pembuatan zeolit menggunakan teknologi yang mudah dan murah. Oleh karena itu jika abu cangkang kelapa sawit bisa diubah menjadi zeolite sebagai pembangun deterjen ramah lingkungan, maka selain membantu untuk pengolahan limbah, juga dapat menjadi sumber penghasilan, income pendapatan keluarga, khususnya keluarga buruh sawit dalam meningkatkan kesejahteraan hidupnya [6]. Dengan demikian, pemanfaatan abu cangkang kelapa sawit untuk sintesis zeolite 4a yang dapat dimanfaatkan sebagai pembangun deterjen selain mengatasi masalah lingkungan juga dapat dikembangkan untuk menjadi usaha sampingan bagi keluarga melalui pembuatan deterjen bubuk, deterjen cream, dan cair ramah lingkungan dengan bahan pengisi/zat pembangun zeolite 4A dari abu cangkang kelapa sawit [7,8].

Kuamang kuning merupakan salah satu daerah trans dari beberapa daerah yang ada di Provinsi Jambi, terletak di kabupaten Muaro Bungo. Hasil wawancara yang dilakukan oleh tim pengabdian, masyarakat di desa Kuamang Kuning memiliki penghasilan 
utama dari perkebunan, terutama Kelapa

Sawit, dan sebagai lainnya berkebun Karet secara minoritas. Secara komposisi suku, penduduk di desa Kuamang Kuning pada umumnya masyarakat pendatang dari jawa, sunda, batak, padang, dan suku pribumi Jambi.

Permasalah yang sering terjadi adalah limbah tandan kosong kelapa sawit dan cangkang kelapa sawit yang biasanya hanya dibakar sehingga menimbulkan pencemaran lingkungan. Hanya sebagian kecil yang dimanfaatkan masyarakat sebagai alat untuk pakan ternak dan bahan bakar. Sebagian besar masyarakat belum memiliki pengetahuan bahwa abu tandan kosong dan cangkang kelapa sawit dapat dimanfaatkan sebagai bahan pembangun deterjen. Pada saat ini, masyarakat lebih memilih deterjen yang dijual di pasaran. Deterjen yang dijual di pasaran pada umumnya mengandung bahan pembangun STPP (Sodium Tri Poly Phosphate) yang dapat membentuk eutrofikasi di permukaan air yang menyebabkan hewan di dalam air tidak mendapatkan oksigen dan STTP menyuburkan tanaman gulma aceng gondok yang menyebabkan danau kekeringan bahkan bisa berubah menjadi daratan. Sebagai alternatif, telah dikembangkan penggunaan zeolite 4A sebagai builder dalam deterjen. Deterjen dengan bahan pembangun zeolite 4A ini ramah lingkungan karena zeolite 4A sebagai pembangun zeolite 4A dapat dimanfaatkan sebagai pupuk bagi tanaman palawija. Zeolit 4A dapat dimanfaatkan sebagai pupuk bagi tanaman palawija. Zeolit dapat dibuat dengan menggunakan limbah abu cangkang kelapa sawit melalui proses yang mudah, mudah, dan sederhana berupa reaksi hidrotermal dalam suasana basa. Dengan demikian pemanfaatan abu sekam padi untuk sintesis zeolite 4A sebagai pembangun deterjen selain mengatasi masalah lingkungan juga dapat dikembangkan menjadi usaha sampingan bagi keluarga melalui pembuatan deterjen bubuk dan krim yang ramah lingkungan dengan bahan pengisi/zat pembangun zeolite 4A dari abu cangkang kelapa sawit $[9,10,11]$. Berdasarkan hasil wawancara dan pengamatan yang dilakukan oleh tim pelaksana pengabdian ke Desa Kuamang Kuning Kabupaten Bungo, Jambi, maka diperoleh beberapa permasalahan mitra yaitu: 1. Mitra Desa Kuamang Kuning Kabupaten Bungo, Jambi kurang memahami dalam pengelolaan limbah tanaman yang baik.

2. Sulitnya mitra dalam mendapatkan deterjen yang ramah lingkungan (relatif aman) dibandingkan deterjen lainnya, yang bersifat sintesis.

3. Masih terdapatnya sistem teknologi pengelolaan limbah cangkang kelapa sawit yang bersifat tradisional dengan membakarnya saja, ataupun hanya dijadikan pupuk.

4. Kurangnya pengetahuan dan pemahaman masyarakat dalam menggunakan deterjen dan sabun yang baik dan tidak mengandung senyawa kimia yang berbahaya. 


\section{METODE PELAKSANAAN KEGIATAN}

Pelaksanaan program ini dilakukan di Desa Kuamang Kuning Kecamatan Ilir, Kabupaten Bungo Jambi, dengan memanfaatkan aula kantor desa dan daerah kebun masyarakat. Pelaksanaan dilakukan pada bulan. Beberapa tahapan dalam pelaksanaan program ini adalah: Melakukan tinjauan lokasi pelaksanaan program dan pembentukan tim yang terdiri dari 40 orang dan setiap tim terdiri dari 2 orang. 1) Memberikan penyuluhan dan Tanya jawab dengan kelompok tani di Desa Kuamang Kuning, Kabupaten Tebo tentang limbah tandan kosong kelapa sawit dan penggunaannya menjadi zeolite $4 \mathrm{~A}$ sebagai bahan pembangun deterjen. 2) Memberikan penyuluhan tentang teknologi pengolahan abu tandan kosong kelapa sawit menjadi zeolite 4A sebagai bahan pembangun deterjen yang ramah lingkungan. 3) Mempersiapkan peralatan pembuatan program dan mendapatkan bahan utama yakni abu tandan kosong kelapa sawit dari penggilingan. 4) Memberikan pelatihan dan pendampingan pada praktek cara pembuatan Zeolit 4A dengan menggunakan bahan baku limbah tandan kosong kelapa sawit. 5) Memberikan pelatihan dan pendampingan pada praktek pembuatan deterjen bubuk dan cream dengan bahan pembangun Zeolit 4A yang dihasilkan dari tandan kosong kelapa sawit kepada peserta program yakni petani dan ibu rumah tangga yang menjadi produsen. 6) Memberikan penyuluhan dan memotivasi kelompok tani di Desa Kuamang
Kuning Kabupaten Bungo untuk membuka wirausaha baru produk Zeolit 4A dari limbah tandan kosong kelapa sawit dan produk sabun cream, sehingga dapat dijadikan sebagai usaha industri kecil yang menjadikan masyarakat mandiri dan produktif.

\section{Peserta Program dan Pendampingan Program}

Peserta program yang menjadi target adalah petani dan masyarakat sekitar khususnya ibu rumah tangga. Pelaksanaan program mempersiapkan tempat dan peralatan yang dibutuhkan. Pelaksanaan program memberikan penyuluhan kepada masyarakat mengenai pengelolaan limbah tandan kosong kelapa sawit menjadi zeolite hingga menjadi deterjen ramah lingkungan dengan proses pengelolaannya dilakukan oleh peserta program dan masyarakat didampingi oleh pelaksana program. Hal ini bertujuan agar masyarakat selaku peserta program menjadi masyarakat yang mandiri dan produktif. Selanjutnya pelaksana program memberikan motivasi agar peserta program menjadikan proyek ini sebagai lahan usaha berupa home industri.

\section{HASIL DAN PEMBAHASAN}

Pelaksanaan program ini diawali dengan diskusi awal dengan masyarakat untuk mempersiapkan kegiatan pelatihan. Dari hasil koordinasi tersebut, dijadwalkan untuk dilakukan pelatihan pada tanggal 30 Juli 2020. Kegiatan diawali dengan pembukaan oleh sambutan dan pembukaan oleh Kepala Desa. Selanjutnya tim dosen memberikan pemaparan tentang kandungan abu cangkang kelapa sawit, deterjen sintesis, dan 
pemanfaatan abu cangkang kelapa sawit sebagai deterjen.

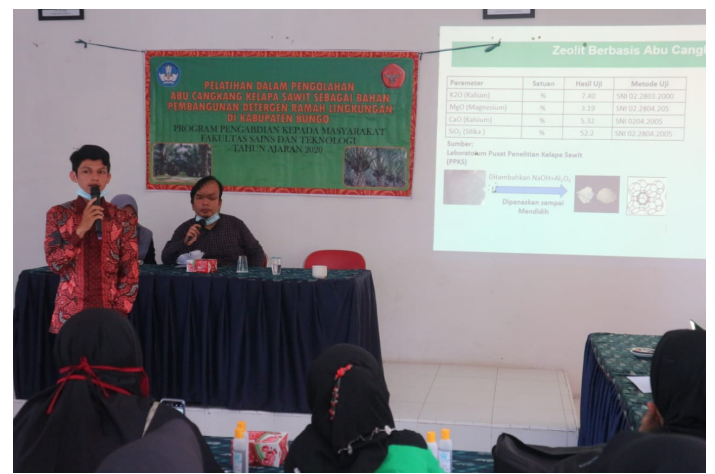

Gambar 1. Tim dosen kimia menyampaikan materi pelatihan

Jumlah masyarakat yang menjadi perwakilan dalam kegiatan ini adalah 32 orang. Dengan menggunakan aula kecamatan yang relatif luas, sehingga tidak begitu padat dan dapat menjaga protokol kesehatan dimasa pandemi. Masyarakat begitu antusias mendengarkan pemaparan dari tim dosen kimia UNJA dan sesekali memberikan pertanyaan dan membangun suasana diskusi.

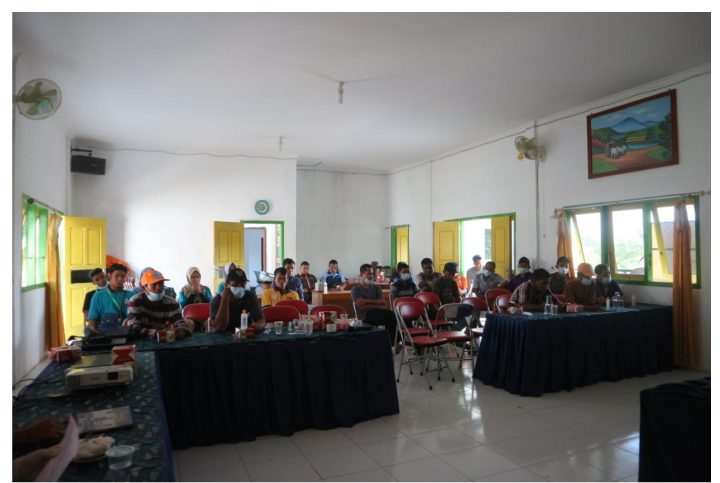

Gambar 2. Masyarakat yang mendengarkan penjelasan dari tim dosen kimia UNJA

Kegiatan dilanjutkan dengan praktik langsung. Masyarakat dibagi menjadi beberapa kelompok untuk memudahkan dalam pelatihan. Masyarakat diberikan prosedur pelatihan, alat, dan bahan-bahan untuk melakukan pembuatan deterjen.

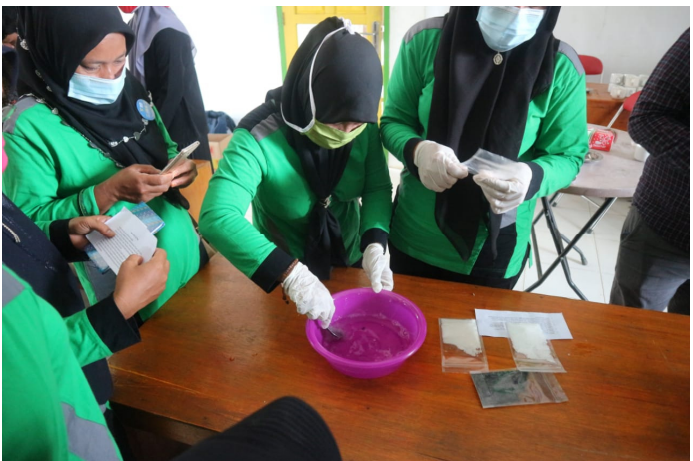

Gambar 3. Masyarakat melakukan praktek langsung membuat deterjen

Melalui prosedur pembuatan deterjen masyarakat secara langsung menambahkan bahan satu persatu. Ada dua bentuk sediaan yang berhasil dibuat yaitu deterjen krim dan deterjen serbuk. Bahan yang telah dipersiapkan untuk membuat deterjen krim adalah Carboxyl Methyl Celulose (CMC), Soda Ash, Zeolit 4A abu cangkang kelapa sawit, Causatic Soda,ABS, kaolin, pewarna parfum, dan air secukupnya. Sedangkan untuk membuat deterjen serbuk digunakan beberapa bahan: Texapone, LAS, $\mathrm{Na}_{2} \mathrm{SO}_{4}$, Soda ash, zeolite 4A abu cangkang kelapa sawit, Enzyme AR, extrrableach, BT Lipozyme, BT Protease, dan Parfum secukupnya.

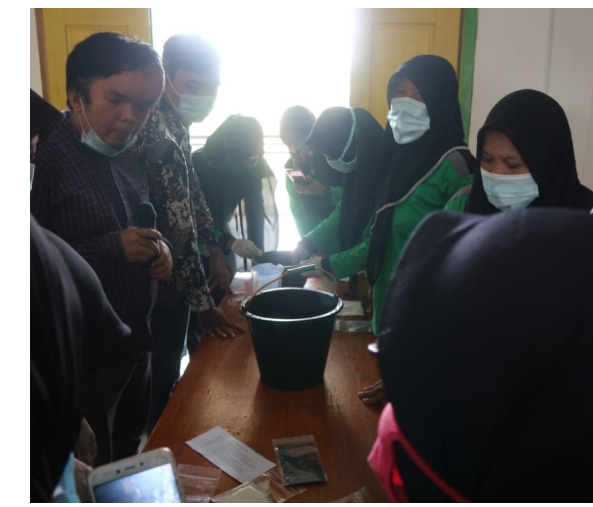

Gambar 4. Masyarakat melakukan praktek langsung membuat deterjen

Hasil deterjen yang dibuat dapat digunakan oleh masyarakat sebagai produk sehari-hari. Masyarakat memberikan respon 
positif terhadap kegiatan ini dan merasakan manfaat terhadap kompetensi mereka, terutama para petani kelapa sawit.

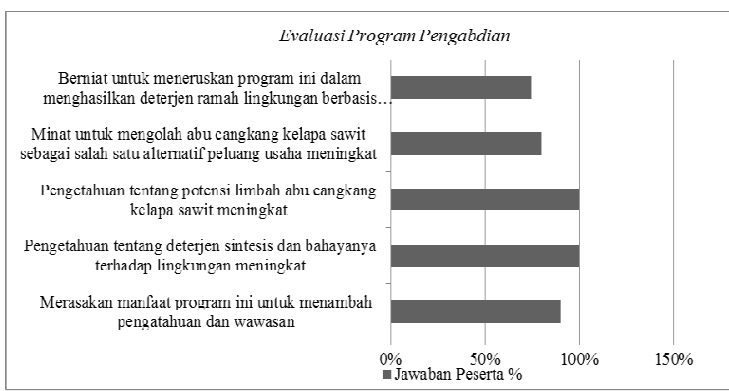

Gambar 5. Hasil evaluasi pengabdian

Pada akhir sesi tim dosen memberikan kuisoner kepada 32 responden dalam kegiatan ini untuk memberikan penilaian terhadap output dan outcome dari kegiatan yang telah diselenggarakan. Sebanyak 90\% masyarakat peserta pelatihan yang hadir merasakan manfaat program ini untuk menambah pengatahuan dan wawasan, $100 \%$ merasakan ada pengaruh peningkatan pengetahuan tentang deterjen sintesis dan bahayanya terhadap lingkungan, serta pengetahuan tentang potensi limbah abu cangkang kelapa sawit. Sekitar $80 \%$ masyarakt berminat untuk mengelola abu cangkan kelapa sawit sebagai salah satu alternatif peluang usaha, serta $75 \%$ berniat untuk meneruskan program ini.

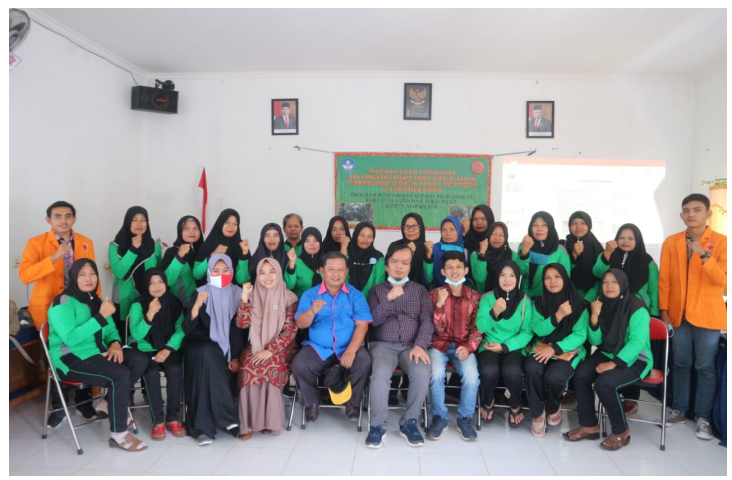

Gambar 6. Foto bersama tim dosen dan masyarakat

\section{KESIMPULAN}

Masyarakat berperan aktif dalam pelatihan pembuatan detergen ramah lingkungan. Pelatihan ini memberikan peningkatan kompetensi bagi masyarakat, sebanyak $90 \%$ masyarakat peserta pelatihan yang hadir merasakan manfaat program ini untuk menambah pengatahuan dan wawasan, $100 \%$ merasakan ada pengaruh peningkatan pengetahuan tentang deterjen sintesis dan bahayanya terhadap lingkungan, serta pengetahuan tentang potensi limbah abu cangkang kelapa sawit dan sekitar $80 \%$ masyarakat berminat untuk mengelola abu cangkan kelapa sawit sebagai salah satu alternatif peluang usaha, serta $75 \%$ berniat untuk meneruskan program ini.

\section{UCAPAN TERIMAKASIH}

Terima kasih kepada LPPM Universitas Jambi atas dana PNBP Tahun 2019.

\section{REFERENSI}

[1] Badan Pusat Statistik Bungo 2014. Bungo dalam Angka. Badan Pusat Statistik Bungo

[2] Muis, L., Permana, E., Anwar, H. 2019. Aplikasi Zeolite dari Cangkang Kelapa Sawit Pada Penyerapan Logam Kromium Heksavalen (Cr6+) Heksavalen Pada Industri Elektroplating. Jurnal Daur Lingkungan, 2(1), 1-6

[3] Asia, N., Akbar, F., Irianty, R.S. 2016. Sintesis Zeolit 4A Dari Abu Limbah Sawit Dengan Variasi Suhu Pembentukan Gel Dan Variasi Volume Natrium Silikat Dengan Natrium Aluminat, Jom FTEKNIK, 3(2), 1-6

[4] Sugiarti, S., Charlena, N.A. Aflakhah. $2017 . \quad$ Zeolit Sintetis Terfungsionalisasi 3-(Trimetoksisilil)1-Propantiol sebagai Adsorben Kation $\mathrm{Cu}$ (II) dan Biru Metilena. Jurnal Kimia VALENSI, 3(1), 11-19 
[5] Goenadi, D. H. (2004). Teknologi Pengolahan Zeolit Menjadi Bahan yang Memiliki Nilai Ekonomi Tinggi, Jurnal Zeolit Indonesia, 3(1), 42-49.

[6] Petranovskii,V., Chaves-Rivas,F., Espinoza, M.A.H., Pestryakov, A., Kolobova, E. 2016. Potential uses of natural zeolites for the development of new materials: short review. MATEC Web of Conferences. 85. 01014

[7] Rahmalia, Winda, et al. 2011. Pemanfaatan Potensi Tandan Kosong Kelapa Sawit (Elais Guineensis Jacq) Sebagai Bahan Dasar C-Aktif Untuk Adsorpsi Logam Perak Dalam Larutan. Pontianak: Universitas Tanjungpura.

[8] Susanto, J.P., Susanto, A.D., Suwendi, N. 2017. Perhitungan Potensi Limbah Padat Kelapa Sawit untuk Sumber Energi Terbaharukan dengan Metode LCA. Jurnal Teknologi Lingkungan, 18(2), 165-172

[9] Aina, H. Nuryono, Tahir, I. 2007. Sintesis Aditif Semen $\beta$-Ca2SiO4 dari Abu Sekam Padi dengan Variasi
Temperatur Pengabuan Seminar Nasional "Aplikasi Sains dan Matematika dalam Industri” UKSW. Salatiga; Jurusan Kimia, FMIPA, Universitas Gadjah Mada; 2007. hlm. 2

[10] Putro, A. L., Prasetyoko. 2007. Abu Sekam Padi Sebagai Sumber Silika Pada Sintesis Zeolit ZSM-5 Tanpa Menggunakan Templat Organik. Akta Kimia Indonesia. 3(1), 33-36.

[11] Sihombing, Sabar. 2010. Perbandingan Efektivitas Arang Aktif dan Silika Gel dari Sekam Padi Sebagai Adsorben Logam CU (II), Skripsi. Medan: Jurusan Kimia, FMIPA, UNIMED, 2010.

Ummah, S. 2010. Kajian Penambahan Abu Sekam Padi dari Berbagai Suhu Pengabuan terhadap Plastistas Kaolin, Skripsi. Malang: Jurusan Kimia, FMIPA, UIN Maulana Malik Ibrahim. 